Received: November 27, 2017

\title{
Research on the Correlation between Regional Economy and Educational Investment Based on Coordinated Development Theory
}

\author{
Jilu Zhang ${ }^{1}$ \\ Henan university of economics and law
}

\begin{abstract}
The quality of human resources in a country or region will exert a great impact on its economic development. With the development of high-end science and technology, this impact will become more obvious. However, in terms of China's investment in public education resources in recent years, there is a huge gap compared with developed countries and even the international average level. By summarizing the rapid economic development experience of the United States, Japan and South Korea, this paper studies the role of educational investment in China's economy based on coordinated development theory, and explores the factors that play a central role in China's future economic development. It is concluded that only by increasing investment in education, especially in primary education, and improving the quality of human resources can the economy in country continue to grow.
\end{abstract}

\section{Keywords}

Educational Investment • Coordinated Development Theory • Economy • Quality of Human Resources

*Project: Philosophy and social science planning project of Henan (2015CJJ036); Title of the Project: Research on Development Model and Path of Promoting the new urbanization in HeNan Province Under the Perspective of Ecological Civilization ${ }^{1}$ Correspondence to: Jilu Zhang (PhD), Henan university of economics and law, Zhumadian 450046, China. Email: jilu19860317@126.com

Citation: Zhang, J.L. (2018). Research on the Correlation between Regional Economy and Educational Investment Based on Coordinated Development Theory. Educational Sciences: Theory \& Practice, 18(5), 2547-2553. http://dx.doi.org/10.12738/estp.2018.5.157 
Since the reform and opening up, China's economy has been growing rapidly. Even in the global economic downturn, it can still maintain a high growth rate (Pretorius \& Xue, 2003). The reason for this phenomenon is that on the one hand, due to the reform of the economic system, the power contained in the system has been exerted; on the other hand, the physical capital accumulated by the reform and opening up has greatly promoted economic development (Altbach, 1999). Studies have shown that in the 1950s to 1980s, the contribution of capital investment to China's economic growth was nearly $35 \%$. By the 1990s, this proportion was as high as nearly 50\% (Lamprinakis, 2012). Therefore, it can be seen that China's rapid economic development has relied heavily on large aunt of capital investment over a long time.

Admittedly, the capital investment is an important factor in economic development. However, large amount of capital investment and low quality of human resources will lead to serious waste of resources and environmental pollution. With the development of science and technology and the improvement of the public's awareness of environmental protection, China's economy is bound to shift from the extensive development of large amount of capital investment to the intensive growth mode based on scientific and technological progress and human resources quality (Liu et al., 2016). Education can effectively improve the quality of human resources, so educational investment will certainly play an important role in China's future economic development. This paper analyzes the economic development experience of foreign developed countries, analyzes the influencing factors of China's economic growth based on the coordinated development theory and proposes corresponding suggestions based on the current situation of educational investment in China.

\section{Interaction between Educational Investment and Economic Development}

\section{Factors Affecting Economic Growth}

It is found by research that factors affecting the economic growth include: capital, labor, technological development and quality of human resources. In the early stage of agricultural social and industrial economic development, due to material deprivation and poor technology, the amount of physical capital and labor is an important condition to promote the economic growth (Gochioco, 2000). With the accumulation of material capital and the advancement of science and technology, the role of human resource quality in economic development has become increasingly prominent. After entering the post-industrial economy era, the role of physical capital in the society will gradually decline and the development of human resource quality and science and technology will inevitably become the decisive force for economic development.

\section{Role of Education in Economic Growth}

By improving the quality of human resources and promoting the development of science and technology, education can increase labor productivity and reduce physical capital consumption, which plays an important role in promoting economic development (Gochioco, 1991). As the creator of science and technology, human capital is also the disseminator and user of new technologies. Through human capital, new technologies can be 
quickly transformed into productivity. With the increasing depletion of resources and serious environmental pollution, the economic development mode of resource-for-development has no longer adapted to the current society. Only by increasing investment in education and improving the quality of human resources can the economy maintain rapid and sustainable development.

\section{Relationship between Education and Economic Development}

There is a mutual influence and mutual constraint relationship between education and economic development (Miller, Villella \& Xia, 2010). On the one hand, the education can promote economic growth by improving the quality of human resources, thereby enhancing the economic strength of a country or region; also, the economic strength plays a decisive role in educational investment and development scale. On the other hand, due to the obvious periodicity and delay of education, it cannot play a quick and obvious stimulation role in economic development; also, the educational investment will inevitably lead to the decrease in the expenditure in other aspects, which will temporarily delay the growth of economic strength.

\section{Analysis of Economic Development Experience in Developed Countries and Its Enlightenment to China}

The analysis of the rapid economic development in the United States, South Korea and Japan can play an important reference role in the future economic development of China.

\section{United States}

From 1870 to 1913, the annual growth rate of GDP in the United State was nearly 4\%, surpassing the United Kingdom. By comparing the economic development and average education level in the United States and the United Kingdom (see Table 1 for details), it can be seen that there is a clear relevance in the growth of average education level and GDP development in the United States. Education not only improves the overall quality of workers, but cultivates a large number of technical, management and innovative talents. Human capital has become the core driving force for the economic growth in the United States.

Table 1

Comparison of Average Education Years and Economic Development Level Between the United States and

\begin{tabular}{lccc} 
Britain & & & \\
\hline Year & 1821 & 1875 & 1913 \\
\hline The United States /Britain (Per capita GDP) & $74 \%$ & $77 \%$ & $1.1 \%$ \\
The United States / Britain (average education years) & $88 \%$ & $89 \%$ & $91 \%$ \\
\hline
\end{tabular}

\section{South Korea}

Before 1945, the illiteracy rate in Korea was as high as $80 \%$. After realizing the importance of educational investment, the South Korean government adhered to the governing philology and took the improvement of human resource quality as a national development strategy. In 1960, South Korea popularized primary education. In the 1970s, South Korea began to develop higher education. In 1995, the enrollment rate of higher 
education reached $90 \%$. With the increasing investment in education, the Korean economy has developed rapidly. From 1965 to 1992, the GDP in South Korea grew at an average annual rate of nearly $9 \%$.

\section{Japan}

Japan's per capita GDP has increased nearly 30 times in less than two hundred years. As a country with scarce natural resources, Japan's rapid development is inseparable from the government's emphasis on education: from 1913, the per capita education years in Japan was 68\% that of the United States. In 1992, this figure developed to $82 \%$. In the past 20 years, Japan's education funds have accounted for more than $6 \%$ of GDP. Japan is the most successful country in achieving rapid economic development through the increase of educational investment.

\section{Enlightenment}

The rapid development of the United States, South Korea, and Japan's economy is inseparable from the heavy educational investment of the government and the growth of per capita education years. In the past few decades, although China's economy has also achieved rapid development, institutional innovation and physical capital investment are the main influencing factors of China's economic development. The growth rate of education funds in China is only $38 \%$ that of GDP and equal proportion of growth has not been achieved, which is significantly different from the above-mentioned countries. Therefore, in order to achieve sustainable and healthy economic development in China, it is necessary to increase the proportion of education investment.

\section{Role of Education in China's Economic Growth}

The growth of national income brought by the enhancement of the education level of workers can be calculated by simplifying the factors of national economic growth to the increase in the number workers and working rate (the education level of workers and technical equipment), thus obtaining the contribution of education to national income.

\section{Contribution of Education to Economic Growth}

According to the labor simplification coefficient (Paap, Dubelaar, Gunnink \& Post, 2012), China's per capita GDP is calculated, as shown in Table 2.

Table 2

The Cultural Composition and Average Labor Simplification Coefficient of Chinese Social Workers in the Past 1982-2000 Years

\begin{tabular}{lccc}
\hline The main factors of national income growth & 1982 & 1991 & 2000 \\
\hline $\begin{array}{l}\text { The actual number of workers in China } \\
\text { (ten thousand of people) }\end{array}$ & 45387 & 56820 & 71625 \\
$\begin{array}{l}\text { Total labor volume after simple labor } \\
\text { (ten thousand of people) }\end{array}$ & 47930 & 61094 & 80721 \\
The proportion of increased labour volume to total labour volume (\%) & 5.67 & 7.68 & 11.6 \\
$\begin{array}{l}\text { Gross domestic product(Hundreds of millions of RMB) } \\
\text { An increase in income due to higher education level of laborers (Hundreds of } \\
\text { millions of RMB) }\end{array}$ & 2594 & 8930 & 25245 \\
GDP per capita (RMB/ per capital) & 139 & 678 & 3002 \\
\hline
\end{tabular}




\section{Analysis of National Income Growth}

Based on the calculation, from 1982 to 1990, China's GDP increased by more than 630 billion yuan and the number of social workers actually increased by 114.43 million. If the labour productivity remained unchanged, then the GDP in 1990 was 324.6 billion yuan while the actual GDP was 893 billion yuan. The extra 560 billion yuan was obtained because of the increase in labour productivity. Among them, the education level of workers increased by nearly $9 \%$. From 1990 to 2000, the increase of the education level of workers contributed to nearly $15 \%$ of the growth of national income.

\section{Contribution of Education at Different Stages to Economic Growth}

According to the labour simplification coefficient, the total index of social simple education years is 114 . The weight of education at each stage of the total index of education years is: $49 \%$ in primary schools, $32 \%$ in junior high schools, $11 \%$ in high schools and $8 \%$ in colleges and universities. Therefore, with the limited funding for education in the country or region, the increase of the investment in primary and junior high schools can more effectively promote regional economic growth.

\section{China's Education Status and Suggestions}

Education plays a decisive role in the economic development of the country or region. Therefore, the sustainable and healthy development of China's economy is inseparable from the vigorous investment in education. However, there are still some problems in the current situation of education in China, mainly including:

\section{Low Educational Funding}

The state's emphasis on education is usually measured by the proportion of educational funding to GDP and per capita public educational funding. The proportion of fiscal educational funding in China is lower than the world average level. Although the absolute value of educational funding has increased significantly, its proportion in GDP is still low.

\section{Large Differences between Urban and Rural Areas}

The educational funding invested in rural areas in China is much lower than that in urban areas, resulting in a low education level of the rural population. The lack of education in rural areas leads to a slow increase in rural income. At the same time, a large amount of low-end labour force is stranded in rural areas, which not only creates large surplus-labour market, but poses certain hidden danger to public security. As an integral part of the China's economy, the rural economy is an important index measuring the economic development in China and thus the investment in rural education should be increased. 


\section{Suggestions}

In view of the problems existing in the educational investment in China, this paper proposes the following suggestions:

(1) Increase the proportion of public educational funding. Governments at all levels have the responsibility to popularize public education and increase the proportion of educational funding.

(2) Pay attention to the investment in primary education. The contribution rate of primary education in promoting China's economic development is greater and limited funding should be invested into primary education, which can stimulate the economic growth more efficiently.

(3) Increase investment in rural education. It is necessary to increase the proportion of educational funding in rural areas and ease the difficulty of educational fund-raising in poverty-stricken areas.

(4) Encourage the establishment of schools run by the non-governmental sectors. By introducing social capital and developing diversified schools, we can make full use of social resources and save educational funding.

(5) Guarantee the special funding for education only. Since education cannot achieve immediate effect for economic development, some local governments do not place education at an important position and may misappropriate educational funding. Therefore, it is necessary to impose strict law regulation and systematic management and develop a relatively complete tracking and inspection mechanism.

\section{Conclusion}

In order to ensure the sustainable and healthy development of China's economy, we should abandon the previous extensive growth model that relies on strong capital investment and turn to the growth model of improving the quality of labour resources by increasing educational investment. This paper studies the relevance between regional economy and educational investment based on coordinated development theory and draws the following research conclusions:

(1) By studying the economic development process of developed countries, it is concluded that the increase in educational investment and the extension of education years can exert a strong stimulating effect on economic development;

(2) According to the labour simplification coefficient: from 1982 to 1990, the increase of the education level of workers contributed to nearly $9 \%$ of the growth of national income; the proportion increased to nearly $15 \%$ from 1990 to 2000 .

(3) With limited educational funding, the priority should be given to primary education, which can play a more significant role in economic development;

(4) Based on the huge difference in educational funding between urban and rural areas in China, the government should encourage the establishment of schools run by the non-governmental sectors and the limited 
Zhang / Research on the Correlation between Regional Economy and Educational Investment...

$\overline{\text { educational funding should be invested more in rural education. Also, the use of educational funding must be }}$ strictly examined and tracked.

\section{References}

Altbach, P. G. (1999). The logic of mass higher education. Tertiary Education \& Management, 5(2), 105-122.

Gochioco, L. M. (1991). High-resolution areal (3-D) seismic survey over a coal mine reserve area. In SEG Technical Program Expanded Abstracts 1991, 592-595. Society of Exploration Geophysicists.

Gochioco, L. M. (2000). High-resolution 3-d seismic survey over a coal mine reserve area in the U. S.-A case study. Geophysics, 65(3), 712-718. http://dx.doi. org/10.1190/1.1444770

Lamprinakis, L. (2012). Organizational innovation and institutional change: the case of Valio in Finland. International Journal on Food System Dynamics, volume 03(2), 95-105. http://dx.doi. org/10.18461/ijfsd.v3i2.321

Liu, Z. N., Song, C. Y., Li, Z. Y., Cai, H. P., Yao, X. M., Hu, G. M. (2016). 3D modelling of geological anomalies based on segmentation of multiattribute fusion. Applied Geophysics, 13(3), 519-528. http://dx.doi. org/10.1007/s11770-016-0579-4

Miller, R. D., Villella, A., \& Xia, J. (2010). Shallow high-resolution seismic reflection to delineate upper 400 $\mathrm{m}$ around a collapse feature in central Kansas. Environmental Geosciences, 4(3), 119-126.

Paap, B. F., Dubelaar, C. W., Gunnink, J.L., \& Post, A. P. (2012). Unravelling the shallow geology of the western Wadden sea using high resolution seismics. Netherlands Journal of Geosciences, 91(3), 341-355. http://dx.doi. org/10.1017/S0016774600000482

Pretorius, S. G., \& Xue, Y. Q. (2003). The transition from elite to mass higher education: A Chinese perspective. Prospects, 33(1), 89-101. http://dx.doi. org/10.1023/A:1022616532317 